\title{
Udržitelný rozvoj České republiky - Blýská se na lepší časy?
}

\section{Eduard Petiška}

Envigogika 9 (2) - Inspirace/ Inspiration

Publikováno/Published 31. 10. 2014

DOI: $\underline{10.14712 / 18023061.459}$

\begin{abstract}
Abstrakt
Článek pojednává o diskuzním semináři Společnosti pro trvale udržitelný život (STUŽ), v jehož rámci byla prezentována Rada vlády pro udržitelný rozvoj (RVUR). Účastníci panelové diskuze vystoupili s př́íspěvky $\mathrm{v}$ nichž představili jak dosavadní činnosti RVUR, tak i její nedávno probělou rekonstrukci a vize do budoucna. V následné diskuzní části byly probírány jednotlivé aspekty udržitelného rozvoje v České republice i v zahraničí, pozornost byla věnována také současné činnosti a předpokládaným aktivity RVUR. Diskutovalo se napr. o institucionálním ukotvení Rady, problematice tvorby prognóz a strategií a vzdělávání k udržitelnému rozvoji.
\end{abstract}

\section{Klíčová slova:}

Udržitelný rozvoj; strategie udržitelného rozvoje; Rada vlády pro udržitelný rozvoj 


\section{Úvod}

Společnost pro trvale udržitelný život (STUŽ) uspořádala v úterý 4. listopadu 2014 v Domě techniků na Novotného lávce $\mathrm{v}$ Praze pozoruhodnou akci v rámci svých pravidelných diskuzních seminářů. Tř́hodinová debata o činnosti Rady vlády pro udržitelný rozvoj (RVUR) nazvaná Jaké jsou cíle a funkce Rady vlády pro udržitelný rozvoj aneb Blýská se na lepší časy? Účastníci z řad členů STUŽ studentů různých humanitních oborů zcela zaplnili přednáškový sál a tím přispěli k značně zvýšené koncentraci oxidu uhličtého v mísnosti.

K vysoké účasti přispěl nejen zájem o činnost Rady, ale i možnost poslechnout si zajímavé osobnosti, které vystoupily v panelové diskuzi. Tu moderoval Ing. Jiř́i Dlouhý, člen RVUR a předseda STUŽ. Zúčastnili se jí také další členové RVUR - známý politik a současný ředitel Odboru poradců a poradkyň předsedy vlády PhDr. Vladimír Špidla, významný český ekolog a politik prof. RNDr. Bedřich Moldan, CSc., d.h.c a ředitelka Odboru pro udržitelný rozvoj na Úřadu vlády České republiky PhDr. Anna Kárníková, která je také tajemnicí Rady. Př́itomni byli rovněž zástupci neziskového sektoru - Ing. Petr Lebeda, zakladatel a ředitel Pražského institutu pro globální politiku Glopolis a český biolog a místopředseda STUŽ prom. biol Pavel Šremer. Diskuzní seminář uvedl Jiří Dlouhý, který krátce představil STUŽ a její aktivity, a posléze samotnou debatu. V úvodu nastínil historii vzniku a fungování RVUR. Ta nejprve fungovala při Úřadu vlády a poté se $z$ důvodů politické nepřízně přesunula na Ministerstvo životního prostředí (MŽP) a její činnost byla částečně utlumena důrazem na environmentální pilír. Rozhodnutím současné vlády se Rada vrátila zpět na Úřad vlády. Po tomto úvodu do problematiky již představil jednotlivé diskutující a předal jim slovo.

Jako první promluvil Vladimír Špidla, který účastníkům nastínil koncepci antropocénu, současného stavu planety a udržitelného rozvoje. Zdůraznil, že klíčovým prvkem a rozhodujícím okamžikem pro udržitelný rozvoj je schopnost společnosti zacházet sama se sebou. Poté se věnoval situaci v České republice a nedostatečné schopnosti českého systému vládnutí vytvářet strategické představy, což má negativní důsledky pro udržitelný rozvoj. Z tohoto důvodu se také podílel na obnovení RVUR, v němž sehrál důležitou úlohu. V př́íspěvku popsal průběh dosavadní činnosti RVUR a důležitost jejího ukotvení na Úřadu vlády České republiky a zároveň podřízení premiérovi jako jejímu předsedovi.

Po Vladimíru Špidlovi přednesla svůj př́íspěvek Anna Kárníková, která přítomné uvedla do způsobu, jakým funguje Odbor pro udržitelný rozvoj, a jak spolupracuje s RVUR. Nejprve se zabývala kontextem fungování Odboru. Vyzdvihla prŕznivou politickou situaci, která poskytuje prŕležitost nefungovat pouze na operativní úrovni, nýbrž vytvářet dlouhodobější struktury. Jako další pozitivní fakt zmínila přijetí zákona o státní službě, který přispěje ke stabilizaci agend a navázání agend na různé resorty, což je také možnost, jak agendu udržitelného rozvoje na Úřadu vlády udržitelně zakotvit. Jako třetí dobrou zprávu uvedla programové prohlášení současné vlády, ve kterém vláda deklaruje přijetí závazku udržitelného rozvoje. Poté se věnovala jednotlivým principům, na kterých je postavena činnost odboru. Nejdříve zmínila rovnováhu všech pilírư udržitelného rozvoje, tedy podporu nejen environmentálního, ale i sociálního a ekonomického pilíře. Dalším důležitým principem je zaměření se na procesy řizení, tedy schopnost komunikace nejen s politiky, ale i se strategickými útvary ministerstev, a využití evropských fondů. Jako třetí princip uvedla veřejné pưsobení, to znamená komunikaci s veřejností. Za tímto účelem došlo také k obnově Fóra pro Udržitelný rozvoj. To se bude konat každoročně jako centrální událost komunity, která existuje kolem udržitelného rozvoje. Letošní ročník se uskuteční již v pátek 28. listopadu 2014 od 10.00 do 16.00 v Lichtenštejnském paláci u parku Kampa. Anna Kárníková na něj posluchače srdečně pozvala. Fórum zahájí premiér České republiky a předseda Rady vlády pro udržitelný rozvoj Bohuslav Sobotka. Hlavním hostem Fóra bude Simon Upton, ředitel Direktorátu OECD pro životní prostředí. Jako čtvrtý princip zmínila posílení mezinárodní spolupráce a mezinárodnich vazeb na OECD, OSN, popř. další organizace, a výměnu dobré praxe a komunikace s dalšími resorty. V závěru vyjádřila naději, že se Odbor a RVUR stanou něčím na způsob určitého gravitačního centra udržitelného rozvoje, které bude propojovat všechny druhy aktérů.

Poté byl vyzván ke slovu Pavel Šremer, jenž v minulosti vypracovával různé strategie udržitelného rozvoje. Pavel Šremer svůj příspěvek podložil powerpointovou prezentací Několik námětů pro práci RVUR a jejích výborů aneb odstraňme zaostávání, která je k dispozici k volnému stažení zde. V prezentaci zmínil náměty jak věcné, tak organizační. Vyzdvihl zejména nutnost finančního zajištění jednotlivých aktivit, stejně jako odborného zázemí a evropskou a mezinárodní spolupráci. 
Na prezentaci Pavla Šremra navázal další zástupce neziskového sektoru, Petr Lebeda, jako předseda sdružení, které se snaží koordinovat společný postup a př́ípravu neziskových organizací zabývajících se především rozvojovou, vzdělávací a environmentální tematikou i akademické sféry v prrípravě na Evropský rok rozvoje. Ten navazuje na připravované prrijetí koncepce sady budoucích mezinárodních rozvojových cílů Cílů udržitelného rozvoje, které by měly propojit environmentální a rozvojové proudy v rámci udržitelného rozvoje. Tyto cíle, jež mají být univerzální, se budou týkat rozvojových i rozvinutých zemí. Měly by být schváleny na podzim příštího roku a bylo by je vhodné implementovat i v rámci České republiky. Na této agendě by pak bylo dobré spolupracovat naprríč jednotlivými resorty (a ne pouze v rámci MŽP, jak tomu bylo dosud). Agenda by měla být transformativní a vést $\mathrm{k}$ strukturálním změnám. Apeloval na důležitost zapojení soukromého sektoru do implikace opatř̌ení zaměřených na udržitelný rozvoj a zejména na potřebu vytyčit si tzv. společný narativ, tedy cíle udržitelného rozvoje České republiky a jejich komunikaci např́č společností. Zmínil také zajímavou publikaci, kterou vytvořil Zelený kruh ve spolupráci s Českým fórem pro rozvojovou spolupráci (FoRS) s názvem Cesta k celistvosti a sebe-vědomé Česko: Př́ležitosti nejen pro rozvojové a ekologické organizace po roce 2015 ( $\mathrm{k}$ dispozici volně ke stažení zde), která se zabývá vizí cílů udržitelného rozvoje pro Českou republiku.

Na závěr přednesl svůj př́spěvek Bedřich Moldan. Vyzdvihl kvalitu předešlých příspěvků a navázal na Pavla Šremra. Pohovořil o českém deficitu v oblasti udržitelného rozvoje, dále pak zmínil důležitost triády, která propojuje občanskou společnost, byznys a státní správu. Vyjádřil potěšení, že proběhla úspěšná resuscitace RVUR, a zdůraznil, že již existuje institucionální základ v podobě Odboru pro udržitelný rozvoj, což je určitý předpoklad pro změnu exekutivní úlohy. Informoval o zasedání RVUR, a jejím usnesení o vytvoření osmi výborů, v jejichž rámci by se měla odehrávat hlavní práce. Bedřich Moldan se stal v rámci RVUR předsedou Výboru pro strategie, který bude vyvíjet aktivitu ve dvou oblastech, a to prostřednictvím pracovních skupin. První oblast se bude věnovat principům udržitelného rozvoje, formulacím základních priorit, zásad a principů $\mathrm{v}$ souvislosti $\mathrm{s}$ kvantifikovnými indikátory, a tím bude pokračovat v existující tradici. Druhá oblast se zaměří na strategickou práci a bude směřovat $\mathrm{k}$ tomu, aby dosavadní zkušenosti, metodiky, strategie a databáze byly analyzovány, vyhodnoceny a na základě výsledků učiněny patřičné závěry. Dále zdůraznil potřebu, aby jednotlivé výstupy byly vázány na určitý vědecký základ a politika udržitelného rozvoje tak byla založena na pevném podkladu tvořeném daty a solidní vědeckou evidencí (tzv. evidence based policy). Na závěr vyjádřil naději, že se bude pokračovat v nedávno učiněných krocích a s pomocí nevládního sektoru, byznysu a státní správy se vývoj vydá správným směrem.

Následovala úrodná diskuze, $\mathrm{v}$ níž probíhala interakce mezi jednotlivými přednášejícími a dalšími účastníky besedy. Diskutující se ve svých otázkách, odpovědích a připomínkách věnovali následující problematice: resortnímu ukotvení RVUR, potřebám analýz, prognóz a důležitosti systematické tvorby strategií, dále územnímu plánování, evropskému institucionálnímu prostředí a ukotvení udržitelného rozvoje $\mathrm{v}$ jeho rámci; dále se diskutovalo na téma vzdělávání $\mathrm{k}$ udržitelnému rozvoji; udržitelný rozvoj v kontextu kompetenčního zákona; lokální i mezinárodní aspekty udržitelného rozvoje; zazněly i diskuzní př́ispěvky $\mathrm{k}$ jednotlivým piliřrom udržitelného rozvoje a dalším tématům. Záznam $\mathrm{z}$ diskuze a celé besedy je volně př́stupný ke shlédnutí zde.

\section{Bc. Eduard Petiška}

Student navazujícího magisterského oboru sociální a kulturní ekologie na FHS UK. $V$ Centru pro otázky životního prostředí Univerzity Karlovy se podílí na chodu odborného recenzovaného periodika Envigogika a vzdělávací platformy Enviwiki, kde rovněž publikuje články. 